\title{
AKTIVITAS ANTIBAKTERI EKSTRAK BIJI KAPULAGA (Amomum compactum Sol. Ex Maton)
}

\author{
ANTIBACTERIAL ACTIVITY OF Amomum compactum \\ Sol. Ex Maton EXTRACT
}

\section{Dede Sukandar, Sandra Hermanto, Eka Rizki Amelia dan Muhamad Zaenudin}

\author{
Program Studi Kimia Fakultas Sains dan Teknologi UIN Syarif Hidayatullah Jakarta \\ Jalan Ir. H. Juanda No 95 Ciputat 15412 Indonesia Telp. (62-21) 7493606 \\ Email: sukandarkimia@uinjkt.ac.id
}

Diterima : 03 Agustus 2015, Revisi : 29 Agustus 2015, Disetujui : 24 September 2015

\begin{abstract}
ABSTRAK
Pengujian aktivitas antibakteri terhadap ekstrak etil asetat biji kapulaga lokal (Amomum compactum Sol. Ex Maton) telah dilakukan. Ekstraksi dilakukan menggunakan metode soxhletasi dengan pelarut metanol dan dipartisi cair-cair dengan pelarut n-heksan, etil asetat dan n-butanol, uji aktivitas antibakteri dilakukan menggunakan metode difusi cakram, fraksinasi menggunakan kromatografi kolom dan karakterisasi fraksi aktif menggunakan kromatografi GCMS, spektoskopi UV-Vis dan FTIR. Hasil uji aktivitas antibakteri diperoleh bahwa ekstrak etil asetat memiliki aktivitas antibakteri tertinggi terhadap $S$. aureus dan E. coli dengan diameter zona hambat masing-masing sebesar $15,15 \pm 1,34$ dan $13,50 \pm 0,70 \mathrm{~mm}$ pada konsentrasi $3200 \mu \mathrm{g} / \mathrm{mL}$. Hasil fraksinasi dari fraksi etil asetat menggunakan kromatografi kolom dengan fase gerak etil asetat : n-heksan (3:2) menghasilkan tiga fraksi yaitu F1 (14,6 mg), F2 (8,1 mg) dan F3 $(4,6 \mathrm{mg})$. Fraksi 2 memiliki aktivitas antibakteri tertinggi terhadap $S$. aureus dengan diameter zona hambat sebesar 12,34 $\pm 0,07 \mathrm{~mm}$ pada konsentrasi $800 \mu \mathrm{g} / \mathrm{mL}$. Hasil karakterisasi fraksi 2 menggunakan analisa GCMS didapatkan tiga senyawa yang diduga bersifat antibakteri yaitu 2,9dihidroksi-1,8-sineol; 2,4-dihidroksi-1,8-sineol dan 2,2'-metilen bis [6-(1,1-dimetiletil)-4-etil] fenol. Hasil karakterisasi fraksi F2 menggunakan spektroskopi UV-Vis menunjukkan adanya gugus kromofor $\mathrm{C}=\mathrm{C}$ terkonjugasi pada $\lambda_{\text {maks }} 223 \mathrm{~nm}$ dan berdasarkan analisa menggunakan FTIR terdapat gugus fungsi $-\mathrm{OH}$ alkohol $\left(3372 \mathrm{~cm}^{-1}\right),-\mathrm{CH}$ alifatik (2926 dan $\left.2854 \mathrm{~cm}^{-1}\right), \mathrm{C}=\mathrm{C}\left(1695 \mathrm{~cm}^{-1}\right), \mathrm{CH}_{2}$ alifatik $\left(1402 \mathrm{~cm}^{-1}\right), \mathrm{CH}_{3}$ alifatik $\left(1384 \mathrm{~cm}^{-1}\right)$, dan $\mathrm{C}-\mathrm{O}$ (1203; 1126; 1091 dan $\left.1043 \mathrm{~cm}^{-1}\right)$.
\end{abstract}

Kata kunci : Antibakteri, S. aureus, E. coli, Amomum compactum Sol. Ex Maton difusi cakram

\section{ABSTRACT}

Testing of antibacterial activity against ethyl acetate extract local cardamom seeds (Amomum compactum Sol. Ex Maton) has been performed. Extraction was carried out using the soxhlet method with methanol solvent and liquid-liquid partitioned with $n$-hexane, ethyl acetate and n-butanol solvent, antibacterial activity test was performed using the disc diffusion method, fractionation using column chromatography and characterization of active fractions using chromatography GCMS, UV-vis and FTIR spectroscopy. The test results showed that the antibacterial activity of ethyl acetate extract had the highest antibacterial activity against $S$. aureus and E. coli with inhibition zone diameter of respectively $15.15 \pm 1.34$ and $13.50 \pm 0.70 \mathrm{~mm}$ at $a$ concentration of $3200 \mathrm{mg} / \mathrm{mL}$. Results of fractionation of the ethyl acetate fraction using column chromatography with a mobile phase of ethyl acetate: n-hexane (3: 2) yielded three fractions, namely F1 (14.6 mg), F2 (8.1 mg) and F3 (4.6 $\mathrm{mg})$. Fraction 2 had the highest antibacterial activity against $S$. aureus with inhibition zone diameter of $12.34 \pm 0.07 \mathrm{~mm}$ at a concentration of $800 \mathrm{ug} / \mathrm{mL}$. The results of the characterization of the fraction 2 obtained using GCMS analysis of three antibacterial compounds suspected of 2.9dihydroxy-1,8-cineol; 2,4-dihydroxy-1,8-cineol and 2,2-methylene bis [6- (1,1-dimethylethyl) -4-ethyl] phenol. The results of the F2 fraction characterization using UV-Vis spectroscopy showed the presence of group $C=C$ conjugated chromophore at $\lambda_{\max } 223 \mathrm{~nm}$ and are based on analysis using FTIR there -OH alcohol functional group (3372 cm-1), aliphatic - $\mathrm{CH}$ (2926 and 2854 $\left.\mathrm{cm}^{-1}\right), C=C\left(1695 \mathrm{~cm}^{-1}\right)$, aliphatic $\mathrm{CH}_{2}\left(1402 \mathrm{~cm}^{-}\right.$ $\left.{ }^{1}\right), \mathrm{CH}_{3}$ aliphatic $\left(1384 \mathrm{~cm}^{-1}\right)$, and $\mathrm{C}-\mathrm{O}(1203 ; 1126$; 1091 and $\left.1043 \mathrm{~cm}^{-1}\right)$. 
Keywords: Antibacterial, S. aureus, E. coli, Amomum compactum Sol. Ex Maton, disk diffusion

\section{PENDAHULUAN}

Pemanfaatan tanaman sebagai obat tradisional pada saat ini terus meningkat yang disebabkan adanya anggapan sebagian besar masyarakat bahwa tanaman obat tidak menimbulkan efek samping, sehingga masyarakat banyak yang memanfaatkan tanaman obat sebagai salah satu alternatif untuk mencegah dan mengobati berbagai macam penyakit ${ }^{(1)}$.

Beberapa tanaman obat diduga memiliki sifat sebagai antibakteri, sehingga dapat dimanfaatkan sebagai antibiotik alami. Salah satunya adalah kapulaga lokal (Amomum compactum Sol. Ex Maton), termasuk famili Zingiberaceae (Gambar 1), merupakan tanaman rempah asli Indonesia yang banyak dimanfaatkan dan memiliki khasiat melegakan tenggorokan, menghilangkan bau mulut, mengobati perut kembung dan radang tenggorokan. ${ }^{(2)}$ Minyak atsiri dan ekstrak metanol dari biji dan buah kapulaga lokal (Amomum compactum Sol. Ex Maton) dilaporkan mampu menghambat pertumbuhan cendawan Botrytis cinerea Pers asal buah anggur (Vitis sp.) dan senyawa sineol diduga merupakan senyawa utama dalam kapulaga lokal yang bersifat sebagai anticendawan $^{(3)}$.

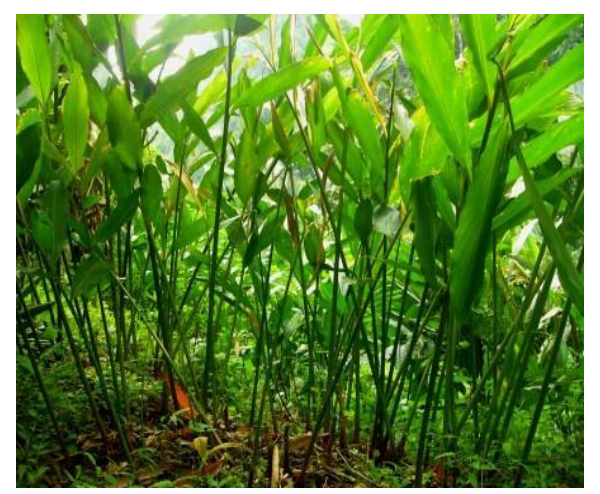

(a)
Hasil penelitian Ağaoğlu, et.al ${ }^{(4)}$ menyatakan ekstrak dietil eter biji kapulaga sabrang (Elettaria cardamomum Maton), memiliki aktivitas antimikroba pada beberapa jenis mikroba yaitu Mycobacterium smegmatis, Klebsiella pneumoniae, Staphylococcus aureus, Escherichia coli, Salmonella typhimurium, Enterococcus faecalis, Micrococcus luteus dan Candida albicans. Selain itu hasil penelitian Islam, et.al ${ }^{(5)}$ menyatakan ekstrak metanol biji kapulaga sabrang (Elettaria cardamomum L. Maton) memiliki aktivitas antibakteri pada konsentrasi $100 \mathrm{mg} / \mathrm{mL}$ terhadap bakteri Gram positif diantaranya $S$. aureus, $\quad$ Streptococcus- $\beta$-haemolytica, Bacillus subtilis, Bacillus megaterium, dan Sarcina lutea dan bakteri Gram negatif diantaranya $K$. pneumoniae, Pseudomonas aeruginosa, $S$. typhimurium, Shigella dysenteriae, dan Shigella sonnei. Penelitian mengenai aktivitas antibakteri kapulaga lokal umumnya menggunakan ekstrak metanol, dietil eter dan minyak atsirinya, tetapi belum dilakukan pengujian aktivitas antibakteri terhadap fraksi etil asetat hasil partisi cair-cair ekstrak metanol. Oleh karena itu, penelitian ini dimaksudkan untuk melakukan pengujian aktivitas antibakteri $S$. aureus dan $E$. coli dan karakterisasi senyawa aktif pada fraksi etil asetat hasil partisi cair-cair ekstrak metanol biji kapulaga lokal (A. compactum Sol. Ex Maton) menggunakan kromatografi GCMS, spektrofotometer UV-Vis dan FTIR.

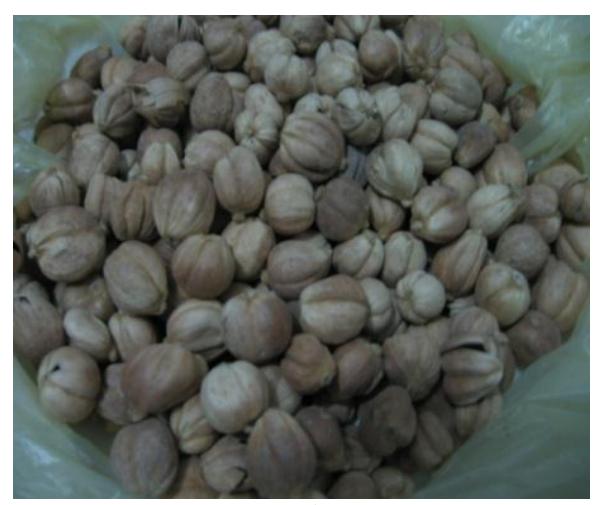

(b)

Gambar 1. (a) Tanaman dan (b) Biji Kapulaga Lokal 


\section{BAHAN DAN METODA}

\section{Bahan Tumbuhan}

Sampel tumbuhan berupa biji kapulaga lokal (Amomum compactum Sol. Ex Maton) yang diperoleh dari Desa Cintaratu, Kecamatan Parigi, Kabupaten Pangandaran, Jawa Barat dan telah dilakukan determinasi di Herbarium Bogoriense, Bidang Botani Pusat Penelitian Biologi LIPI Cibinong, Bogor.

\section{Ekstraksi dan Fraksinasi}

Sebanyak 1,21 kg biji kapulaga lokal yang telah dihaluskan diekstraksi menggunakan ekstraktor soxhlet dengan pelarut metanol sebanyak $250 \mathrm{ml}$ pada suhu $60{ }^{\circ} \mathrm{C}$ selama 7 jam dan ekstrak yang diperoleh dipekatkan menggunakan rotary evaporator. Selanjutnya sebanyak 32 gram ekstrak kasar metanol biji kapulaga lokal difraksinasi dengan metode partisi cair-cair menggunakan pelarut n-heksan, etil asetat dan n-butanol.

\section{Uji Fitokimia}

Uji fitokimia dilakukan pada ekstrak metanol biji kapulaga dan fraksi-fraksi hasil partisi yaitu fraksi n-heksana, fraksi etil asetat dan fraksi n-butanol. Uji fitokimia yang dilakukan meliputi uji alkaloid, flavonoid, terpenoid, steroid, polifenol/ tannin dan saponin.

\section{Uji Aktivitas Antibakteri}

Uji aktivitas antibakteri dilakukan pada ekstrak metanol biji kapulaga dan fraksi-fraksi hasil partisi yaitu fraksi nheksana, fraksi etil asetat dan fraksi nbutanol terhadap bakteri $S$. aureus dan $E$. coli menggunakan metode difusi cakram dengan mengukur diameter zona bening sebagai zona hambat dari sampel yang diuji. Zona hambat yang terukur dari sampel dibandingkan dengan zona hambat dari antibiotik (kloramfenikol) sebagai kontrol positif. Selanjutnya dibuat kurva hubungan antara sampel, antibiotik, kontrol negatif (x) dengan diameter daerah hambat (y).

\section{Kromatigrafi Kolom}

Kromatografi kolom dilakukan pada fraksi teraktif hasil partisis cair-cair berdasarkan hasil uji aktivitas antibakteri dengan fasa diam silika gel Merck $60 \mathrm{GF}_{254}$ $(0,2-0,5 \mathrm{~mm})$ dan fase gerak campuran etil asetat:n-heksana (3:2).

\section{Analisa Kandungan Kimia}

Analisa kandungan kimia dalam fraksi aktif menggunakan spektrofotometer UV-Vis Perkin Elmer Lambda 25 dan FTIR Spektrum One Perkin Elmer.

\section{HASIL DAN PEMBAHASAN}

Ekstrak metanol biji kapulaga lokal (Amomum compactum Sol. Ex Maton) dihasilkan sebanyak 46,17 gram dengan rendemen sebesar 3,8\% dan berwarna coklat kemerahan berbentuk pasta. Pemilihan metode ekstraksi soxhlet dilakukan karena memiliki beberapa keuntungan dibandingkan dengan metode ekstraksi lainnya, yaitu pelarut yang digunakan lebih sedikit dan secara langsung diperoleh hasil yang lebih pekat, proses ekstraksi berlangsung dengan pelarut yang selalu baru sehingga dapat menarik zat aktif yang lebih banyak, dan proses ekstraksi dapat diteruskan sesuai keperluan tanpa perlu menambah volume pelarut (6).

Partisi cair-cair ekstrak metanol biji kapulaga lokal menghasilkan fraksi nheksana $(0,83 \mathrm{~g})$, etil asetat $(6.09 \mathrm{~g})$ dan nbutanol $(7 \mathrm{~g})$ dengan masing-masing rendemen 2,59; 19,03 dan $21,87 \%$ (b/b). 
Hasil fraksinasi menunjukkan bahwa terdapat lebih banyak golongan senyawa semi polar dan senyawa polar dibanding senyawa non polar.

\section{Hasil Uji Fitokimia}

Hasil pengujian fitokimia terhadap ekstrak kasar metanol dan ekstrak hasil partisi caircair tertera pada Tabel 1.

Tabel 1. Hasil Uji Fitokimia Ekstrak Kasar dan Hasil Fraksinasi

\begin{tabular}{ccccc}
\hline $\begin{array}{c}\text { Uji } \\
\text { Fitokimia }\end{array}$ & $\begin{array}{c}\text { Ekstrak } \\
\text { Kasar } \\
\text { Metanol }\end{array}$ & $\begin{array}{c}\text { Ekstrak } \\
\text { Fraksi } \\
\text { n- } \\
\text { heksana }\end{array}$ & $\begin{array}{c}\text { Ekstrak } \\
\text { Fraksi } \\
\text { Etil } \\
\text { asetat }\end{array}$ & $\begin{array}{c}\text { Ekstrak } \\
\text { Fraksi } \\
\text { n- } \\
\text { butanol }\end{array}$ \\
\hline Alkaloid & - & - & - & - \\
Flavonoid & - & - & - & - \\
Fenol & + & - & + & + \\
Tanin & + & - & + & + \\
Terpenoid & + & + & + & - \\
Saponin & - & - & - & - \\
\hline Keterangan : & & & & \\
(+) Menunjukkan hasil positif pada uji fitokimia & \\
(-) Menunjukkan hasil negatif pada uji fitokimia &
\end{tabular}

Hasil uji fitokimia menunjukkan bahwa ekstrak kasar metanol etil asetat biji kapulaga lokal (Amomum compactum Sol. Ex Maton) mengandung senyawa golongan fenol, tanin dan terpenoid. Sedangkan ekstrak n-heksan mengandung terpenoid dan ekstrak n-butanol mengandung fenol dan tanin. Hasil yang diperoleh sedikit berbeda dari hasil penelitian Kaushik, et.al ${ }^{(7)}$ yang melaporkan bahwa ekstrak kasar akuades buah kapulaga sabrang (Elettaria cardamomum Maton) mengandung senyawa golongan alkaloid, tanin, terpenoid dan flavonoid. Pada ekstrak metanol dan fraksi kapulaga lokal tidak terdeteksi adanya alkaloid.

\section{Aktivitas Antibakteri}

Uji aktivitas antibakteri dilakukan terhadap ekstrak metanol, fraksi n-heksana, etil asetat dan n-butanol, serta kontrol positif kloramfenikol maupun kontrol negatif pelarut dimetilsulfoksida (DMSO) menggunakan bakteri uji Staphylococcus aureus dan Escherichia coli yang dilakukan secara in vitro dengan metode difusi cakram. Perbedaan zona hambat masingmasing ekstrak terhadap bakteri $S$. aureus dan $E$. coli terlihat pada Gambar 2 dan 3.

Hasil uji aktivitas antibakteri menunjukkan bahwa ekstrak kasar metanol hanya mampu membentuk zona hambat terhadap bakteri $E$. coli dengan diameter zona hambat tertinggi sebesar 14,00 $\pm 3,39$ mm pada konsentrasi $3200 \mu \mathrm{g} / \mathrm{mL}$ :, tetapi tidak mampu menghambat pertumbuhan $S$. aureus. Hal ini diduga karena ekstrak metanol lebih aktif menghambat bakteri Gram negatif (E. coli) tetapi tidak mampu menghambat bakteri Gram positif ( $S$. aureus), yang disebabkan lebih banyak mengandung senyawa polar. Menurut Moat, et.al ${ }^{(8)}$ senyawa dalam ekstrak polar dapat mudah berpenetrasi pada dinding sel bakteri Gram negatif karena adanya gugus hidrofilik. Selain itu menurut Franklin dan Snow $^{(9)}$ dinding sel bakteri Gram negatif mengandung gugus protein yang disebut porin yang membentuk pori-pori hidrofilik pada lapisan membran luar sel sehingga senyawa polar dapat lebih mudah menembus dinding sel. Sedangkan menurut Davidson dan Branen ${ }^{(10)}$ bakteri Gram positif ( $S$. aureus) lebih sensitif terhadap senyawa non polar yang disebabkan komponen dasar penyusun dinding sel bakteri Gram positif yaitu peptidoglikan yang salah satu penyusunnya adalah asam amino alanin yang bersifat hidrofobik (non polar) sehingga mudah ditembuh oleh senyawa non polar, selain itu menurut Madigan, et.al ${ }^{(11)}$ bakteri Gram positif terdiri dari $90 \%$ peptidoglikan yang mengandung asam amino D-alanin dan lapisan tipis berupa asam teikoat. 


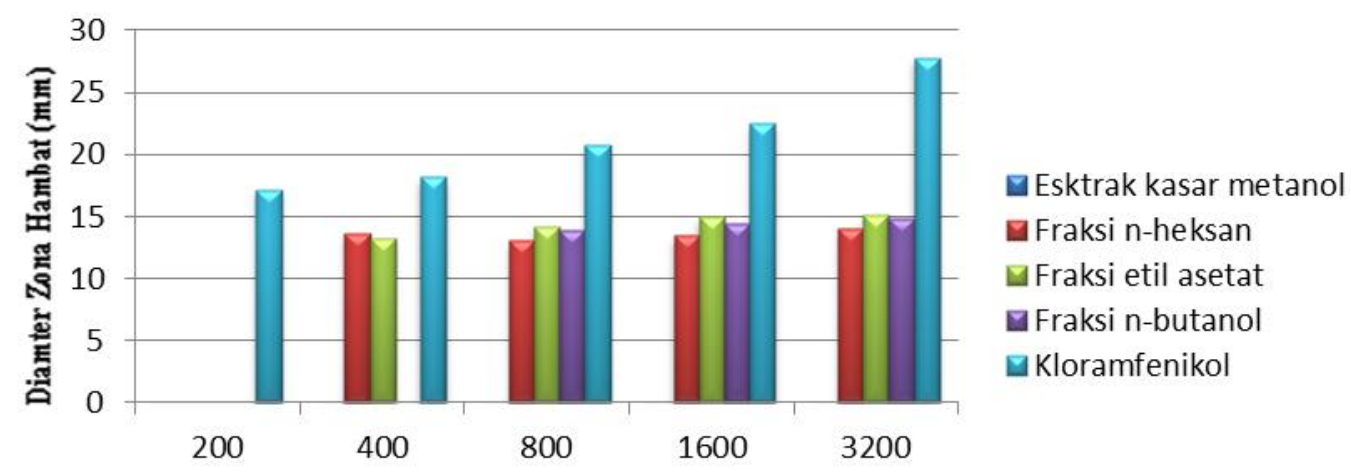

Gambar 2. Hasil Uji Aktivitas Antibakteri terhadap Bakteri S. aureus

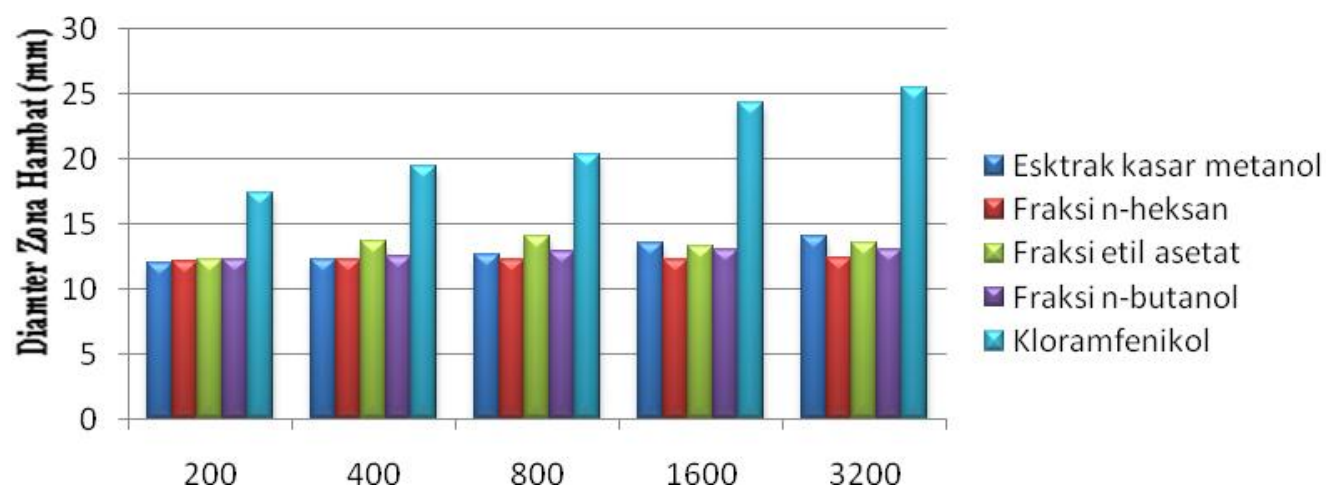

Gambar 3. Hasil Uji Aktivitas Antibakteri terhadap Bakteri E. coli

Ekstrak n-heksana, etil asetat dan nbutanol hasil partisi mampu menghambat pertumbuhan bakteri $S$. aureus maupun $E$. coli. Ketiga ekstrak tersebut memiliki zona hambat terhadap bakteri E. coli pada konsentrasi terendah $200 \mu \mathrm{g} / \mathrm{mL}$ masingmasing sebesar $12,05 \pm 0,35 \mathrm{~mm}, 12,25 \pm$ $0,21 \mathrm{~mm}$ dan $12,30 \pm 0,56 \mathrm{~mm}$. Sedangkan ekstrak n-heksana dan etil asetat memiliki zona hambat pada konsentrasi terendah 400 $\mu \mathrm{g} / \mathrm{ml}$ terhadap bakteri $S$. aureus masingmasing sebesar 13,65 $\pm 1,48 \mathrm{~mm}$ dan 12,30 $\pm 0,98 \mathrm{~mm}$ dan ekstrak n-butanol pada konsentrasi terendah $800 \mu \mathrm{g} / \mathrm{mL}$ memiliki zona hambat sebesar 13,85 $\pm 0,49 \mathrm{~mm}$. Pada konsentrasi $3200 \mu \mathrm{g} / \mathrm{mL}$ adanya peningkatan zona hambat pada fraksi etil asetat terhadap $S$. aureus dengan zona hambat sebesar 15,15 $\pm 1,34 \mathrm{~mm}$.
Berdasarkan hasil uji antibakteri tersebut aktivitas antibakteri terhadap bakteri $S$. aureus mengalami peningkatan, sedangkan terhadap $E$. coli tidak mengalami peningkatan setelah dilakukan pasrtisi caircair. Hal ini diduga karena senyawa antibakteri terhadap bakteri Gram negatif (E. coli) terdistribusi ke dalam masingmasing ekstrak, sehingga daya hambatnya menurun.

Tidak terbentuknya zona hambat pada fraksi n-heksana pada konsentrasi 200 $\mu \mathrm{g} / \mathrm{mL}$; fraksi etil asetat pada konsentrasi $200 \mu \mathrm{g} / \mathrm{mL}$; dan fraksi n-butanol pada konsentrasi $200 \mu \mathrm{g} / \mathrm{mL}$ dan $400 \mu \mathrm{g} / \mathrm{mL}$ terhadap bakteri $S$. aureus diduga kecilnya konsentrasi uji, sehingga belum mampu menyebabkan perubahan sistim fisiologis sel bakteri sehingga bakteri tersebut mampu untuk tumbuh ${ }^{(12)}$. 
Hasil uji antibakteri terhadap kontrol positif antibiotik kloramfenikol menghasilkan zona hambat tertinggi terhadap bakteri $S$. aureus sebesar 27,80 \pm $1,97 \mathrm{~mm}$ dan terhadap bakteri $E$. coli sebesar 25,50 $\pm 0,70 \mathrm{~mm}$ pada konsentrasi $3200 \mu \mathrm{g} / \mathrm{mL}$, sedangkan kontrol negatif DMSO tidak menghasilkan zona hambat pada kedua bakteri uji. Hasil penelitian ini menunjukkan ekstrak kasar metanol biji kapulaga lokal (A. compactum Sol. Ex Maton) dan hasil partisinya memiliki aktivitas antibakteri $S$. aureus yang lebih rendah dari ekstrak metanol dengan zona hambat sebesar $15 \mathrm{~mm}(100 \mathrm{mg} / \mathrm{mL})$ maupun ekstak dietil eter biji kapulaga sabrang (Elettaria cardamomum Maton) yang menghasilkan zona hambat terhadap bakteri $E$. coli dan $S$. aureus masing-masing sebesar $13 \mathrm{~mm}$ dan $30 \mathrm{~mm}^{(4,5)}$.

Besar zona hambat yang dihasilkan ketiga fraksi terhadap bakteri $S$. aureus cenderung lebih besar dibandingkan dengan bakteri $E$. coli. Adanya perbedaan kepekaan pada bakteri Gram positif dan Gram negatif terhadap zat antibakteri yang terkandung dalam ketiga fraksi tersebut diduga karena perbedaan struktur dinding sel bakteri. Menurut Jawetz, et.al ${ }^{(13)}$, perbedaan kepekaan pada bakteri Gram positif dan Gram negatif terhadap zat antibakteri diduga karena perbedaan struktur dinding sel seperti jumlah kandungan peptidoglikan, lipid dan aktivitas enzim yang menentukan penetrasi, pengikatan dan aktivitas antibakteri. Bakteri S. aureus (Gram positif) mempunyai struktur dinding sel yang mengandung polisakarida, protein, dan lipid yang rendah (1-4 \%), sedangkan E. coli (negatif) mempunyai dinding sel dengan kandungan lipid yang tinggi (11-22 \%) serta struktur dinding sel yang berlapis tiga (multilayer) yaitu lipoprotein, membran luar fosfolipid dan lipopolisakarida. Membran luar fosfolipid dan lipopolisakarida dapat mengurangi masuknya zat antibakteri ke dalam sel, sehingga dinding sel bakteri $S$. aureus lebih mudah ditembus oleh zat antibakteri dibandingkan dengan dinding sel bakteri $E$. coli.

Besar diameter zona hambat setiap ekstrak lebih rendah dibandingkan dengan kontrol positif antibiotik kloramfenikol yang merupakan antibiotik berspektrum luas sehingga efektif terhadap bakteri Gram positif maupun Gram negatif ${ }^{(14)}$.

Hasil uji antibakteri menunjukkan bahwa Fraksi 1 tidak memberikan hambatan terhadap kedua bakteri uji, sedangkan Fraksi 2 dan Fraksi 3 hanya mampu menghambat bakteri $S$. aureus. Berdasarkan hal ini, diduga Fraksi 2 dan Fraksi 3 memiliki komponen senyawa yang bersifat antibakteri dengan spektrum sempit yang efektif melawan sebagian bakteri Gram positif ${ }^{(15)}$.

\section{Hasil Kromatografi Kolom}

Hasil kromatografi kolom dengan fase gerak campuran etil asetat:n-heksana (3:2) diperoleh 30 fraksi dan dilakukan penggabungan menjadi 3 fraksi yaitu $F 1$ (fraksi 1-9=14,6 mg), F2 (fraksi 10-18=8,1 mg) dan F3 (fraksi 19-30= 4,6 mg). Fraksi gabungan F1, F2, F3 hasil pemisahan kromatografi kolom dilakukan uji antibakteri terhadap E. coli dan $S$. aureus pada konsentrasi $800 \mu \mathrm{g} / \mathrm{mL}$. Hasil uji antibakteri F1, F2 dan F3 tertera pada Tabel 2.

\section{Hasil Analisa GCMS}

Berdasarkan hasil analisa GCMS diperoleh sedikitnya 20 puncak kromatogram yang menunjukkan adanya dua puluh komponen senyawa yang terdapat dalam Fraksi 2. Adapun kromatogram hasil analisa GCMS terdapat pada Gambar 4 dan Kedua puluh senyawa dari hasil analisa GCMS dapat dilihat pada Tabel 3. 
Tabel 2. Hasil Uji Antibakteri Hasil Pemisahan Kromatografi Kolom

\begin{tabular}{ccc}
\hline \multirow{2}{*}{ Sampel } & \multicolumn{2}{c}{ Diameter Zona Hambat $(\mathbf{m m})$} \\
\cline { 2 - 3 } & Bakteri E. coli & Bakteri S. aureus \\
\hline Fraksi 1 & - & - \\
Fraksi 2 & - & $12,34 \pm 0,07$ \\
Fraksi 3 & - & $12,10 \pm 0,14$ \\
\hline
\end{tabular}

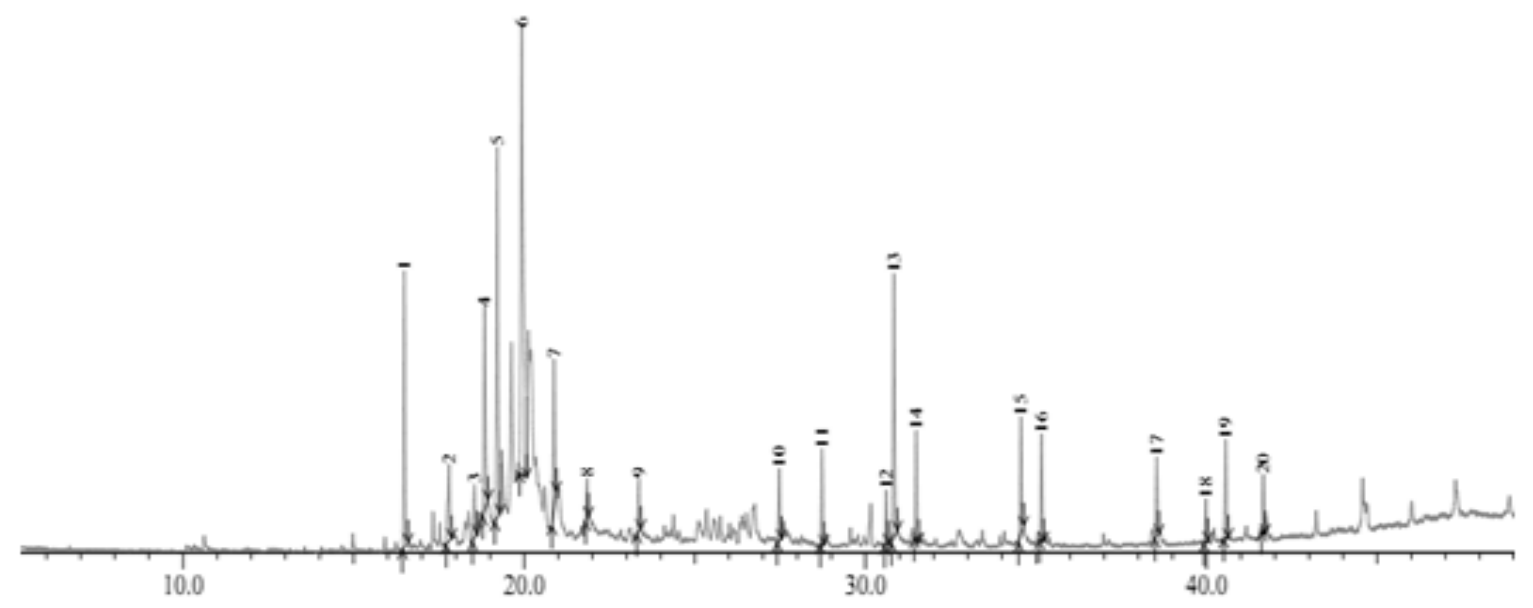

Gambar 4. Kromatogram Hasil Analisa GCMS Fraksi 2

Tabel 3. Komponen Senyawa Fraksi 2

\begin{tabular}{|c|c|c|c|c|}
\hline No. & $\begin{array}{l}\text { Waktu } \\
\text { Retensi }\end{array}$ & $\%$ Area & $\begin{array}{c}\text { Bobot } \\
\text { Molekul }\end{array}$ & Nama Senyawa \\
\hline 1 & 16.486 & 8,17 & 172 & 1,8-terpin hidrat \\
\hline 2 & 17.796 & 3,21 & 186 & 2,4-dihidroksi-1,8-sineol \\
\hline 3 & 18.540 & 1,86 & 170 & Sikloheksanol, 2,2-dimetil-, asetat \\
\hline 4 & 18.840 & 6,69 & 186 & 1,3,3-trimetil-2-oksabisiklo[2.2.2]oktan-6,7- endo,diol \\
\hline 5 & 19,210 & 13,41 & 226 & $\begin{array}{l}\text { 4-(4-hidroksi-2,2,6-trimetil-7-oksabisiklo[4.1.0]hept-1- } \\
\text { il) butan-2-on }\end{array}$ \\
\hline 6 & 19,930 & 24,95 & 186 & 2,9-dihidroksi-1,8-sineol \\
\hline 7 & 20,870 & 4,71 & 170 & $\begin{array}{l}\text { 1-isokuinolinmetanol, } \quad \text { 1,2,3,4-tetrahidro-alfa-fenil-2- } \\
\text { (trifenilasetil) }\end{array}$ \\
\hline 8 & 21,845 & 1,09 & 168 & 3-(2-hidroksi-2-metilpropill)-sikloheksan-1-on \\
\hline 9 & 23,360 & 1,69 & 184 & $\begin{array}{l}\text { 2-hidroksimetil-5-(1-hidroksi-1-isopropil)-2- } \\
\text { sikloheksan-1-on }\end{array}$ \\
\hline 10 & 27,475 & 2,24 & 266 & 1-nonadekana \\
\hline 11 & 28,725 & 2,69 & 282 & Isobutil ftalat \\
\hline 12 & 30,605 & 1,57 & 278 & Dibutil ftalat \\
\hline 13 & 30,835 & 8,38 & 256 & Asam palmitat \\
\hline 14 & 31,490 & 3,40 & 266 & 1-nonadekana \\
\hline 15 & 34,555 & 3,87 & 284 & Asam oktadekanoat \\
\hline 16 & 35,160 & 3,27 & 266 & 1-nonadekana \\
\hline 17 & 38,540 & 2,38 & 354 & 1-tetrakosanol \\
\hline 18 & 39,980 & 1,28 & 368 & 2,2'-metilen bis[6-(1,1-dimetiletil)-4-etil] fenol \\
\hline 19 & 40,560 & 3,12 & 278 & Ester Asam 1,2-benzendikarboksilat, mono (2-etilheksil) \\
\hline 20 & 41,665 & 2,01 & 364 & 1-heksakosena \\
\hline
\end{tabular}


Senyawa yang diduga memiliki aktivitas antibakteri yang terindentifikasi menggunakan GCMS pada fraksi 2 yaitu senyawa pada waktu retensi (Rt) 19,930 dengan persen luas area 24,95 \% yang memiliki kemiripan dengan senyawa 2,9dihidroksi-1,8-sineol (1) dan senyawa pada waktu retensi (Rt) 17.796 dengan persen luas area 3,21 \% yang memiliki kemiripan dengan senyawa 2,4-dihidroksi-1,8-sineol (2).<smiles>CC12CC(CC1O)C(C)(CO)O2</smiles>

(1)<smiles>CC12CC(O)(CC1O)C(C)(C)O2</smiles>

(2)

Menurut Davidson dan Branen ${ }^{(10)}$, sineol merupakan senyawa golongan monoterpen yang dapat memberikan efek penghambatan terhadap mikroba. Hasil penelitian Inouye, et.al ${ }^{(16)}$ menunjukkan senyawa 1,8-sineol yang terdapat dalam minyak atsiri rimpang Zingiber aromaticum Val memiliki aktivitas antibakteri Haemophilus influenzae, Streptococcus pyogens, Streptococcus pneumonia, Staphylococcus aureus dan Escherichia coli. Selain itu penelitian Sukandar, et.al ${ }^{(17)}$ menunjukkan bahwa senyawa sineol dalam minyak atsiri rimpang lengkuas merah (Alpinia purpurata K. Schum) memiliki aktivitas antibakteri Bacillus cereus dan Pseudomonas aeruginosa dengan diameter zona hambat masing-masing $17,6 \mathrm{~mm}$ pada konsentrasi $20 \%$.

Menurut Cowan ${ }^{(18)}$ mekanisme kerja antibakteri senyawa terpenoid dengan cara bereaksi dengan porin (protein transmembran) pada membran luar dinding sel bakteri dan membentuk ikatan polimer yang kuat sehingga mengakibatkan rusaknya porin. Rusaknya porin yang merupakan pintu keluar masuknya senyawa yang dibutuhkan sel bakteri akan mengurangi permeabilitas dinding sel bakteri yang mengakibatkan sel bakteri akan kekurangan nutrisi, sehingga pertumbuhan bakteri terhambat atau mati.

Selain itu senyawa yang diduga memiliki aktivitas antibakteri yaitu senyawa pada waktu retensi (Rt) 39,980 dengan persen luas area $1,28 \%$ yang memiliki kemiripan dengan senyawa 2,2'metilen bis[6-(1,1-dimetiletil)-4-etil] fenol (3).<smiles>CCc1cc(Cc2cc(CC)cc(C(C)(C)C)c2O)c(O)c(C(C)(C)C)c1</smiles>

(3)

Menurut Cowan ${ }^{(18)}$, senyawa fenol, fenolat atau polifenol merupakan salah satu golongan senyawa metabolit sekunder yang memiliki aktivitas antimikroba. Senyawa 2,2'-metilen bis[6-(1,1-dimetiletil)-4-etil] fenol juga ditemukan di dalam ekstrak butanol kulit biji Anacardium excelsum yang memiliki aktivitas antibakteri terhadap bakteri B. Subtillis dengan zona hambat 19 $\mathrm{mm}{ }^{(19)}$. Mekanisme penghambatan bakteri oleh senyawa fenol dengan cara mengganggu komponen penyusun peptidoglikan sel bakteri, sehingga lapisan sel bakteri tidak terbentuk secara utuh ${ }^{(20)}$. Mekanisme senyawa fenol sebagai antibakteri pada konsentrasi rendah dengan merusak membran sitoplasma dan menyebabkan kebocoran inti sel, sedangkan pada konsentrasi tinggi senyawa fenol akan berkoagulasi dengan protein seluler ${ }^{(22)}$. 


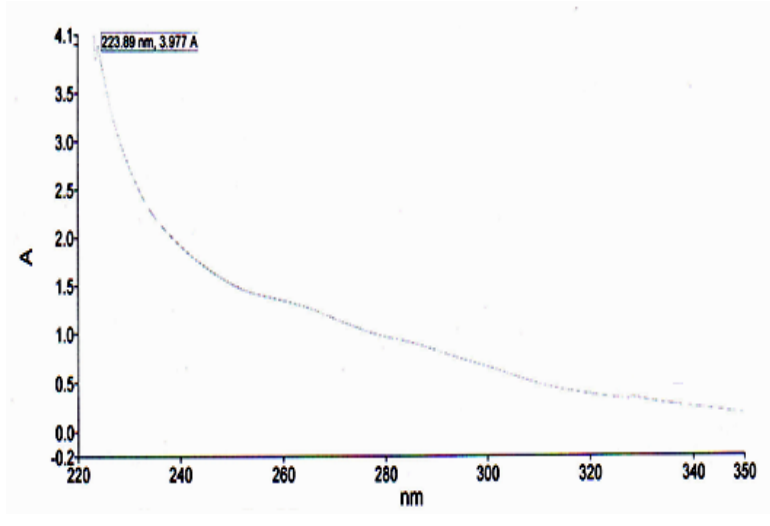

Gambar 5. Spektrum UV Fraksi 2

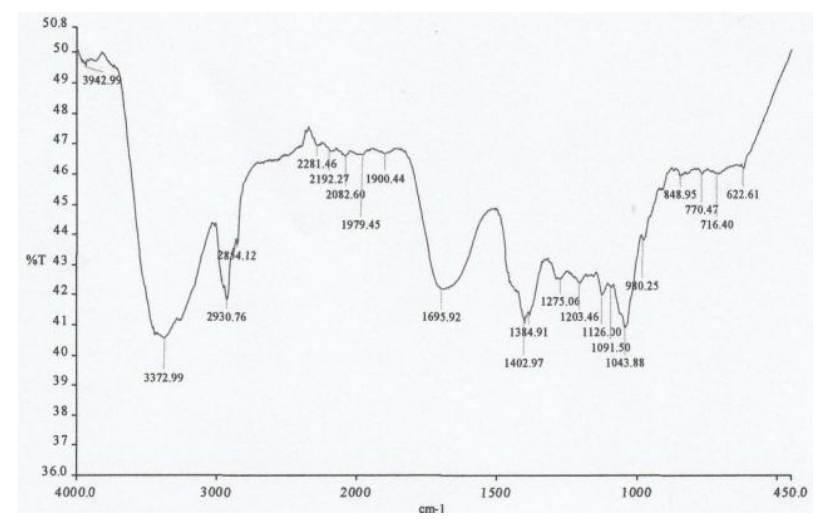

Gambar 6. Spektrum FTIR Fraksi 21

\section{Hasil Analisa Spektroskopi UV-Vis dan Spektroskopi FTIR.}

Hasil analisis spektroskopi UV-Vis Fraksi 2 (Gambar 5) menunjukkan adanya transisi elektron dari $\pi-\pi^{*}$ yang disebabkan kromofor $\mathrm{C}=\mathrm{C}$ terkonjugasi $\left(\lambda_{\text {maks }} 223 \mathrm{~nm}\right)$ (21).

Berdasarkan hasil analisis spektrum IR menunjukkan bahwa fraksi 2 mengandung senyawa yang memiliki gugus fungsi $\mathrm{O}-\mathrm{H}$ yang membentuk ikatan hidrogen intramolekul (v $3372 \mathrm{~cm}^{-1}$ ) dengan intensitas kuat yang diperkuat serapan uluran C-O (v 1203, 1126, 1091 dan $1043 \mathrm{~cm}^{-1}$ ) dengan intensitas lemah dan melebar ${ }^{(21)}$.

Selain itu terdapat pula puncak serapan uluran $\mathrm{C}=\mathrm{C}$ (v $1695 \mathrm{~cm}^{-1}$ ) dengan intensitas kuat dan melebar ${ }^{(23)}$, serta puncak serapan uluran $\mathrm{C}-\mathrm{H}$ dengan intensitas kuat dan tajam (v $2926 \mathrm{~cm}^{-1}$ ) serta intensitas rendah (v $\left.2854 \mathrm{~cm}^{-1}\right)$ yang dihasilkan oleh yang diperkuat adanya serapan tekukan C$\mathrm{H}$ dari $\mathrm{CH}_{2}$ (v $1402 \mathrm{~cm}^{-1}$ ) dan tekukan C-H dari $\mathrm{CH}_{3}\left(v 1384 \mathrm{~cm}^{-1}\right)^{(21)}$.

\section{KESIMPULAN}

Aktivitas antibakteri ekstrak kasar metanol biji kapulaga lokal meningkat setelah dilakukan partisi cair-cair dengan fraksi teraktif fraksi etil asetat terhadap $S$. aureus dengan zona hambat sebesar 15,15 \pm $1,34 \mathrm{~mm}(3200 \mu \mathrm{g} / \mathrm{mL})$ dan terhadap $E$. coli sebesar $14,00 \pm 2,54 \mathrm{~mm}(800 \mu \mathrm{g} / \mathrm{mL})$. Sedangkan Fraksi 2 hasil fraksinasi dari fraksi etil asetat hanya mampu menghambat $S$. aureus dengan zona hambat sebesar $12,35 \pm 0,07 \mathrm{~mm}(800 \mu \mathrm{g} / \mathrm{mL})$.

Hasil analisa GCMS menunjukkan Fraksi 2 memiliki 3 komponen senyawa yang diduga bersifat antibakteri yaitu 2,9dihidroksi-1,8-sineol; 2,4-dihidroksi-1,8sineol dan 2,2'-metilen bis[6-(1,1dimetiletil)-4-etil] fenol.

Hasil analisa UV-Vis dan FTIR menunjukkan Fraksi 2 mengandung senyawa yang memiliki kromofor $\mathrm{C}=\mathrm{C}$ pada $\lambda_{\text {maks }} 223 \mathrm{~nm}$ serta memiliki gugus fungsi $-\mathrm{OH}\left(3372 \mathrm{~cm}^{-1}\right)$, $-\mathrm{CH}$ (2926 dan $\left.2854 \mathrm{~cm}^{-1}\right), \mathrm{C}=\mathrm{C}\left(1695 \mathrm{~cm}^{-1}\right), \mathrm{CH}$ dari $-\mathrm{CH}_{2}$ $\left(1402 \mathrm{~cm}^{-1}\right),-\mathrm{CH}$ dari $-\mathrm{CH}_{3}\left(1384 \mathrm{~cm}^{-1}\right)$, dan C-O (1203, 1126, 1091 dan 1043 $\left.\mathrm{cm}^{-1}\right)$.

\section{SARAN}

Perlu dilakukan pemurnian lebih lanjut menggunakan kromatografi kolom hingga diperoleh senyawa murni dan dianalisa menggunakan spektroskopi NMR serta perlu dilakukan pengujian aktivitas antibakteri menggunakan metode dilusi hingga diperoleh Konsentrasi Hambat Minimum (KHM) dan Konsentrasi Bunuh 
Minimum (KBM) serta uji aktivitas antibakteri terhadap bakteri lainnya

\section{UCAPAN TERIMA KASIH}

Terima kasih kami ucapkan kepada pimpinan dan staf Herbarium Bogoriense Bidang Botani Pusat Penelitian BiologiLIPI Cibinong Jawa Barat, yang telah membantu mengidentifikasi spesimen tumbuhan dan kepada Kepala Pusat Laboratorium Terpadu UIN Syarif Hidayatullah Jakarta yang telah memfasilitasi penelitian ini.

\section{DAFTAR PUSTAKA}

1. M. Poeloengan, M Andrini, N. Susan, I. Komala \& M. Hasnita. Uji Daya Antibakteri Ekstrak Etanol Kulit Batang Bungur (Largerstoremia speciosa Pers) Terhadap Staphylococcus aureus dan Escherichia coli Secara In Vitro. Seminar Nasional Teknologi Peternakan Dan Veteriner, 776-782. 2007.

2. IPTEKnet - Tanaman Obat Indonesia : Kapulaga- tersedia pada http://www.iptek.net.id/. [Diakses pada tanggal 6 Desember 2012 pukul 20.00 WIB. 2012]

3. I. Prasasty, Suranto \& R. Setyaningsih. Aktivitas Anticendawan Biji dan Buah Kapulaga Lokal (Amomum cardamomum Willd.) terhadap Botrytis cinerea Pers. asal Buah Anggur (Vitis sp.), BioSMART, 5(1), 61-64 ISSN: 1411-321 X (2003).

4. S.Ağaoğlu, N. Dostbil \& S. Alemdar. Antimicrobial Effect of Seed Extract of Cardamom (Elettarla cardamomum Maton). YÜ Vet Fak Derg, 16(2), 99101. (2006)
5. S. Islam, A. Rahman, M. I. Sheikh, M. Rahman, A. H. M. Jamal, \& F. Alam. In vitro Antibacterial Activity of Methanol Seed Extract of Elettaria cardamomum (L.) Maton. Agriculturae Conspectus Scientificus, 75(3), 113-117 (2010)

6. J.B. Harborne, Metode Fitokimia, Penuntun Cara Modern Menganalisa Tumbuhan. Penerjemah: K. Padmawinata \& I. Sudiro. Bandung: Institut Teknologi Bandung. 1987

7. P. Kaushik, P. Goyal, A. Chauhan, and G. Chauhan In Vitro Evaluation of Antibacterial Potential of Dry Fruit Extracts of Elettaria cardamomum Maton (Chhoti Elaichi) Iran J Pharm Res. Summer; 9(3): 287-292 (2010)

8. A.G. Moat, J. W. Foster., M. P. Spector. Microbial Physiology Fourth Edition. New York: Wiley-Liss. 2002.

9. T. Franklin, G.A. Snow.. Biochemistry of Antimicrobial Action. London: Chapman and Hall. 1989

10. P.M. Davidson, A.L. Branen. Antimicrobia in Food. New York: Marcel Dekker, Inc.1993.

11. M.T. Madigan, J.M. Martinko, J. Parker. Brock Biology of Microorganisms. Tenth Edition. Southern Illinois: University Carbondale. 2003.

12. I.B.C. Darmayasa, Daya Hambat Fraksinasi Ekstrak Sembung Delan (Sphaerantus indicus L) Terhadap Bakteri Escherichia coli dan Staphylococcus aureus. Jurnal Biologi, XI(2), 74-77 ISSN: 14105292 (2008)

13. E. Jawetz, J.L. Melnick, E.A. Adelberg. Mikrobiologi Kedokteran. Edisi 20. Penerjemah: Edi Nugroho \& R.F. Maulany. Jakarta: Buku Kedokteran EGC, 1986

14. B. Siswandono, Soekardjo. Kimia Medisinal. Surabaya: Airlangga University Press. 1995. 
15. K. Todar, The Control of Microbial Growth. Wisconsin: University of Wisconsin. 1997.

16. S. Inouye, T. Takizawa, H. Yamaguchi. Antibacterial Activity of Essential Oils and Their Mayor Constituents Againts Respiratory Tract Pathogens by Gaeous contact. J. Ant. Chem, 47, 565-573. (2001)

17. D. Sukandar, N. Radiastuti \& S. Utami. Aktivitas Minyak Atsiri Rimpang Lengkuas Merah (Alpinia purpurata K. Schum) Hasil Distilasi. Jurnal Biologi Lingkungan, 3(2), 94-100. (2009)

18. M.M. Cowan. Plant Products as Antimicrobial Agents Clinical. Microbiology Reviews, 12(4), 564-582 ISSN 0893-8512 (1999)

19. C. Celis, A. Garcia, G. Sequeda, G. Mendez, R. Torrenegra. Antimicobial Activity of Extracts Obtained from Anacardium excelsum Againts Some Pathogenic Microorganisms. Emir. J. Food Agric, 23(3), 249-257 (2011)

20. T. Robinson Kandungan Organik Tumbuhan Tinggi. Bandung: ITB. 1995.

21. R.M. Silverstein, G.C. Bassler, T.C. Morrill. Penyidikan Spektrofotometrik Senyawa Organik edisi ke empat. Penerjemah: Drs. A.J. Hartomo \& Dra. Anny Victor Purba, M,Sc. Jakarta: Erlangga. 1986.

22. W.A. Volk, M.F. Wheeler. Mikrobiologi Dasar. Penerjemah: Soenartono Adisoemarto. Jakarta: Erlangga. 1984.

23. U. Supratman, Elusidasi Struktur Senyawa Organik. Bandung: Widya Padjajaran. 2010. 
JKTI, Vol. 17, No. 2, Desember 2015 